\title{
The Devastating Effect of Secondhand Smoking Exposure in Pediatric Intensive Care Admissions
}

\section{Ebeveyn Sigara İçiminin Çocuk Yoğun Bakım Başvurularındaki Yıkıcı Etkisi}

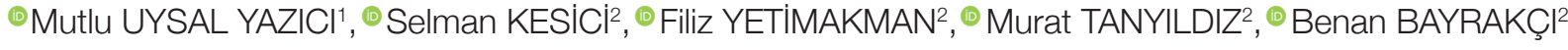

\author{
${ }^{1}$ University of Health Sciences, Dr. Sami Ulus Maternity and Children Training and Research Hospital, Pediatric Intensive Care, \\ Ankara, Turkey \\ ${ }^{2}$ Hacettepe University Faculty of Medicine Ihsan Dogramaci Childrens' Hospital, Department of Pediatric Intensive Care Unit, \\ Ankara, Turkey
}

\begin{abstract}
Objective: We studied the prevalence and potential effects of secondhand parental smoking on the diagnosis, severity of disease, duration of hospitalization and length of stay on mechanical ventilation. The aim of this study was to evaluate the effect of secondhand parental smoking in pediatric intensive care unit patients.

Material and Methods: This cross sectional prospective survey study was conducted as a questionnaire regarding the smoking habits of all parents of hospitalized patients in our pediatric intensive care unit between September 2014 and January 2015.

Results: A total of 125 female and 178 male were included in the study. The median age was 53 (min:1 - max: 216 months). Indications of hospitalizations were intoxication (16.5\%), neurological disorders (14.9\%), malignancy (12.9\%), congenital heart diseases (11.2\%), genetic syndromes (9.9\%), trauma (9.6\%), shock (\%7.3), arrhythmia (6.3\%), renal failure (5\%), diabetes (2.6\%), burns (2.6\%) and metabolic diseases (\%1.3). A total of $42.2 \%$ of patients were on invasive, $5.3 \%$ were on non-invasive mechanical ventilation. Mothers, fathers and guests smoking rates were $40.6 \% ; 75.2 \%$ and $58.4 \%$ respectively. The rate of illiterate fathers and mothers were higher in secondhand parental smoking group compared with non-exposure group ( $6 \%$ vs $4 \%, p=0.004,10.7 \%$ vs $5.7 \%, p=0.21$, respectively). The secondhand parental smoking rate was $76.9 \%$. The secondhand parental smoking rate of children diagnosed as malignancy was $16.4 \%$ compared with non-exposed group (1.4\%) which was statistically significant $(p<0.05)$. There was no significant difference in secondhand parental smoking rate was of children diagnosed as intoxication, trauma, burns and others. The mean length of stay in mechanical ventilator ( MV ) and pediatric risk of mortality score ( PRISM ) score were 5.8 days \pm 6.3 and $11.6 \pm 8$ respectively. The PRISM score was statistically significant in secondhand parental smoking exposed children compared with non-exposed ones ( $12.2 \pm 7.9$ vs $9.6 \pm 7.8 ; p=0.007)$. The length of stay in pediatric intensive care unit (PICU) and duration of mechanical ventilation were longer in children secondhand smoking exposure $(p<0.05)$.
\end{abstract}

Conclusion: Secondhand smoking is related with increased velocity of PICU admissions, severity of disease, increased diagnosis of malignancies, prolonged duration of mechanical ventilation and PICU stay. Besides, secondhand exposed patients are more likely to have low parental education level.

Key Words: Parents, Pediatric intensive care unit, Smoking

\section{öz}

Amaç: Ebeveyn sigara içiminin prevalansı, tanı üzerine etkisi, hastalığın șiddeti, hastanede ve mekanik ventilatörde kalıș süresi üzerine potansiyel etkileri araştıııdı. Bu çalışmanın amacı; ebeveyn sigara kullanımının pediatrik yoğun bakım ünitesi hastalarında etkisini değerlendirmektir.

Gereç ve Yöntemler: Kesitsel prospektif tanımlayıcı olan bu çalıșmada Eylül 2014 - Ocak 2015 tarihleri arasında pediatrik yoğun bakım ünitemizde yatan hastaların ebeveynlerine sigara içme alışkanlıkları ile ilgili anket yapıldı.

Bulgular: Çalışmaya toplam 125 kadın, 178 erkek dahil edildi. Ortanca yaş 53 (min: 1 - maks: 216) aydı. Hastanede yatış tanıları zehirlenme (\% 16.5), nörolojik bozukluklar (\% 14.9), malignite (\% 12.9), doğuștan kalp hastalıkları (\% 11.2), genetik sendromlar (\% 9.9), travma (\% 9.6), şok (\% 7.3), aritmi (\% 6.3), böbrek yetmezliği (\% 5), diyabet (\% 2.6), yanıklar (\% 2.6) ve metabolik hastalıklardı (\% 1.3). Hastaların\% 42.2'si invaziv, \% 5.3' ü non-invaziv mekanik ventilasyondaydı. 
Anneler, babalar ve misafirlerin sigara içme oranları sırasıyla \% 40.6; \% 75.2 ve \% 58.4 bulundu. Ebeveyn sigara kullananlarda okuma yazma bilmeyen kiși sayısı, sigara kullanmayan gruba kıyasla daha yüksekti (sırasıyla \% 6 vs \% 4( anne), p= 0.004, \% 10.7 vs \% 5.7, (baba) $p=0.21)$. Ebeveyn sigara içme oranı \% 76.9 iken, Türkiye'deki sigara içme prevalansı tüm nüfusta \% 30.5 olması Çocuk Yoğun Bakım'a kabul edilen hastalarda ebeveyn sigara içim oranının artmış olduğunu göstermektedir. Ebeveyn sigara öyküsü olan çocukların \%16.4' ü malignite tanısı alırken sigara içmeyen grupta bu oran \%1.4' tü ( $p<0.05)$. Ebeveyn sigara içen ile içmeyen grup arasında zehirlenme, travma, yanıklar ve diğer tanılar açısından anlamlı fark yoktu. Ortalama Mekanik ventilatörde kalış süresi ve Pediatrik Mortalite Riski (PRISM) skoru sırasıyla 5.8 gün \pm 6.3 ve $11.6 \pm$ 8'di. PRISM skoru ebeveyn sigara içen çocuklarda içmeyenlere göre istatistiksel olarak anlamlı yüksekti. (12.2 \pm 7.9 vs $9.6 \pm 7.8 ; p=0.007)$. Pediatrik yoğun bakım ünitesinde kalma süresi ve mekanik ventilasyon süresi ebeveyn sigara maruziyetinde daha uzundu ( $\mathrm{p}<0.05)$.

Sonuç: Ebeveyn sigara içiciliği, çocuk yoğun bakım yatış sıklığında artış, hastalığın şiddeti, artmış malignite tanısı, uzun süreli mekanik ventilasyon süresi ve çocuk yoğun bakım yatış süresi ile ilişkilidir. Ayrıca, ebeveyn sigara maruziyeti olan hastaların ebeveyn eğitimi düzeyinin düşük olduğu görülmektedir.

Anahtar Sözcükler: Ebeveyn Çocuk yoğun bakım, Sigara

\section{INTRODUCTION}

Exposure to parental secondhand smoke (SHS) is one of the major risk factors for children's health (1). The health problems are exacerbated with increasing exposure duration to SHS (2-3). Children are more vulnerable to harmful effects of SHS compared to adults. Different factors like the length of exposure, total area of smoking place, count of respiration during exposure, might affect the degree of danger on health of children. Increased frequency of mainly respiratory tract associated acute and chronic diseases are detected in SHS exposed children compared with non-exposed counterparts (4). Prenatal SHS exposure also affects growth rates of newborn infants (5), while postnatal exposure mainly acts as a trigger factor for respiratory symptoms, impaired lung function and asthma attacks (6). Public health programs promoting strict household smoking rules should be encouraged in order to optimize the potential consequences of passive smoking on pediatric patients (7-10). In Turkey, despite enforcement of major healthcare policies and some success in decreasing the rate of smoking, one-third of the Turkish women and nearly half of the men are smokers (11).

The current study mainly aims to reveal the prevalence and potential effects of secondhand parental smoking on the diagnosis, severity of disease, duration of hospitalization and length of stay on mechanical ventilation in pediatric patients hospitalized in PICU.

\section{MATERIAL and METHODS}

This cross-sectional prospective study was conducted in Hacettepe University Faculty of Medicine, Insan Dogramaci Childrens Hospital, Department of Pediatric Intensive Care Unit between September 2014 - January 2015. This study was approved by the Medical Ethics Committee of the university, and informed consent was obtained from each family prior to the study.
Parents whose children were hospitalized in the our Pediatric Intensive Care Unit were asked to fill up the questionnaire. The questionnaire included: gender, age, educational status, smoking habits of parents and family history of chronic diseases. Educational status of parents were classified into: no education, elementary school, high-school and university. Admission diagnosis, presence of pneumonia or any respiratory disease, the need and duration of invasive or non invasive ventilatory support of the eligible children were recorded.

PRISM scores of children were determined using the method described by Pollack and colleagues (12).

\section{Statistical analysis}

Statistical analysis was performed by using SPSS 18 version (Statistical Package for Social Sciences, SPSS Inc, Chi- 106 cago, IL). Descriptive statistics were given as mean and standard deviation (SD) for normally distributed variables or median and interquartile range (IQR) for variables that were not normally distributed. Categorical data were presented as number and/or percentage. Chi square for categorical variables and independent samples $t$ test (for parametric continuous variables) or Mann-Whitney $U$ test (for non- parametric continuous variables) was used for univariate analysis. All quantitative results were reported with $95 \%$ confidence intervals. Statistical significance was set at $p<0.05$.

Binary logistic regression analysis was proceeded to evaluate the second hand smoke as dependent variable and model test statistic was demonstrated as significant.

\section{RESULTS}

During the study period, 303 parents; 125 female (41.25 $\%)$ and 178 male (58.75\%) were included in the study. The demographic features of parents and children were represented in (Table I). Median age was 53 (min - max: 1-216 months) months. Diagnosis of hospitalizations were intoxication (16.5\%), neurological disorders (14.9\%), malignancy (12.9\%), congenital heart disease (11.2\%), genetic syndromes (9.9\%), 
Table I : Demographic features of patients and parents.

\begin{tabular}{|c|c|c|c|c|}
\hline Sex (\%) & \multicolumn{2}{|c|}{$\begin{array}{l}\text { Secondhand Parental Smoking } \\
\qquad(n=233)\end{array}$} & \multicolumn{2}{|c|}{$\begin{array}{l}\text { No Smoking Exposure } \\
(n=70)\end{array}$} \\
\hline $\begin{array}{l}\text { Male } \\
\text { Female }\end{array}$ & $\begin{array}{l}133 \\
100\end{array}$ & $\begin{array}{l}(57.1) \\
(42.9)\end{array}$ & $\begin{array}{l}45 \\
25\end{array}$ & $\begin{array}{l}(64.3) \\
(35.7)\end{array}$ \\
\hline Age $($ mean \pm SD $)$ & $87 \pm 74$ & & $64.7 \pm 69$ & \\
\hline $\begin{array}{l}\text { Education status of p } \\
\text { Mother } \\
\text { Illiterate } \\
\text { Primary high school } \\
\text { University }\end{array}$ & $\begin{array}{c}25 \\
185 \\
23\end{array}$ & $\begin{array}{c}(10.7) \\
(79.4) \\
(9.9)\end{array}$ & $\begin{array}{c}4 \\
55 \\
11\end{array}$ & $\begin{array}{l}(5.4) \\
(78.6) \\
(15.7)\end{array}$ \\
\hline $\begin{array}{l}\text { Father } \\
\text { Illiterate } \\
\text { Primary high school } \\
\text { University }\end{array}$ & $\begin{array}{c}14 \\
186 \\
33\end{array}$ & $\begin{array}{c}(6) \\
(79.6) \\
(14.2)\end{array}$ & $\begin{array}{c}3 \\
45 \\
22\end{array}$ & $\begin{array}{l}(4.3) \\
(64.3) \\
(31.4)\end{array}$ \\
\hline $\begin{array}{l}\text { Pneumonia(\%) } \\
\text { Yes } \\
\text { No }\end{array}$ & $\begin{array}{c}85 \\
148\end{array}$ & $\begin{array}{l}(36.5) \\
(63.5)\end{array}$ & $\begin{array}{l}19 \\
51\end{array}$ & $\begin{array}{l}(27) \\
(73)\end{array}$ \\
\hline $\begin{array}{l}\text { Disease of Lung(\%) } \\
\text { Yes } \\
\text { No }\end{array}$ & $\begin{array}{l}115 \\
118\end{array}$ & $\begin{array}{l}(49.4) \\
(50.6)\end{array}$ & $\begin{array}{l}30 \\
40\end{array}$ & $\begin{array}{l}(42.9) \\
(57.1)\end{array}$ \\
\hline $\begin{array}{l}\text { Ventilation(\%) } \\
\text { Yes } \\
\text { No }\end{array}$ & $\begin{array}{l}110 \\
123\end{array}$ & $\begin{array}{l}(47.4) \\
(52.6)\end{array}$ & $\begin{array}{l}31 \\
39\end{array}$ & $\begin{array}{l}(44.3) \\
(55.7)\end{array}$ \\
\hline $\begin{array}{l}\text { Diagnosis of Hospitali } \\
\text { Neurological } \\
\text { Cardiac_Shock } \\
\text { Intoxication_Trauma } \\
\text { Genetic\&Metabolic } \\
\text { Malignancy }\end{array}$ & $\begin{array}{l}32 \\
69 \\
69 \\
25 \\
38\end{array}$ & $\begin{array}{l}(13.7) \\
(29.6) \\
(29.6) \\
(10.7) \\
(16.3)\end{array}$ & $\begin{array}{c}13 \\
29 \\
18 \\
9 \\
1\end{array}$ & $\begin{array}{l}(18.6) \\
(41.4) \\
(25.7) \\
(12.9) \\
(1.4)\end{array}$ \\
\hline
\end{tabular}

Table II: Logistic regression analysis of second hand smoke with clinical parameters.

\begin{tabular}{|l|c|c|c|c|}
\hline \multicolumn{1}{|c|}{ Variable } & OR & \multicolumn{2}{c|}{$\mathbf{9 5 \%}$ C.I. (OR) } & p \\
\hline Age (month) & 1.004 & 1.000 & 1.008 & 0.069 \\
\hline Length of Ventilation & 0.950 & 0.897 & 1.005 & 0.075 \\
\hline PRISM score & 1.06 & 1.013 & 1.107 & 0.011 \\
\hline Outcome of Patients $^{3}$ & 1.297 & 0.320 & 5.264 & 0.716 \\
\hline Length of stay in PICU $^{\prime}$ & 1.982 & 0.863 & 1.117 & 0.002 \\
\hline Mechanical Ventilation $^{1}$ & 1.899 & 0.428 & 1.889 & 0.035 \\
\hline Malignancy $^{2}$ & 10.413 & 1.382 & 78.458 & 0.023 \\
\hline Constant $^{2}$ & 1.312 & & & 0.372 \\
\hline
\end{tabular}

1: Yes, 2: No, 3: Exitus, PICU: Pediatric intensive care unit; PRISM: Pediatric risk of mortality score, OR: Odds ratio

trauma $(9.6 \%)$, shock $(7.3 \%)$, arrhythmia $(6.3 \%)$, renal failure (5\%), diabetes $(2.6 \%)$, burns $(2.6 \%)$ and metabolic disease (1.3\%). Total $42.2 \%$ of patients were on invasive and $5.3 \%$ were on non-invasive MV.

Mother, father and guest smoking rates were $40.6 \% ; 75.2 \%$ and $58.4 \%$ respectively. The SHSR (secondhand smoke rate) was $76.9 \%$. Multivariate regression analysis showed that SHSR were significantly correlated with increased PRISM score, hospital and MV length of stay and malignancy. In patients who exposed to SHS the risk of increased PRISM score at time of PICU hospitalization was 6\% increased (OR: 1.06, $p=0.011$ ). In addition to that in patients with SHS exposure compared with non-exposure patients risk of malignancy was increased by 10,4 times (OR: 10.4, 95\% Cl min: $1.3-\max : 78.4, p=0.023$ ) (Table II).

There was statistically significant association with history of smoking package/year and diagnosis of malignancy $\left(x^{2}=4.038\right.$; $p=0.044)$. The package/year number of parents were summed. The median of total package/year was detected as 23 (min max : 1-140) and the group was divided in two according to median 23 package/year. It was found that 104 patients (88.9\%) in the 1-23 package/year class did not have malignancy and 25 patients (21.7\%) in the 24 and above package/year class had malignancy. It was demonstrated that non-malignant patients were predominantly in the 1-23 package/year class and those with malignancy were predominantly in the package/ year class of 24 and above (Table III).

The secondhand parental smoking rate of children diagnosed as malignancy was $16.4 \%$ compared with non-exposed group $(1.4 \%)$ which was statistically significant $(p<0.05)$. No significant 
Table III: Multivariate analysis of clinical parameters according to the package/year smoking history of parents.

\begin{tabular}{|c|c|c|c|}
\hline \multirow[t]{2}{*}{ Variable } & \multicolumn{2}{|c|}{ Smoking package/year } & \multirow{2}{*}{$\begin{array}{c}\text { Statistical Analysis* } \\
\text { Probability }\end{array}$} \\
\hline & 1-23 package/year & $>23$ package/year & \\
\hline Length of stay in PICU (day) & $3.0[1.0-26.0]$ & $4.0[1.0-34.0]$ & $\begin{array}{c}Z=-0.146 \\
p=0.884\end{array}$ \\
\hline $\begin{array}{l}\text { Mechanical Ventilation } \\
\text { No } \\
\text { Yes }\end{array}$ & $\begin{array}{l}60(\% 51.3) \\
57(\% 48.7)\end{array}$ & $\begin{array}{l}60(\% 54.1) \\
51(\% 45.9)\end{array}$ & $\begin{array}{l}\chi^{2}=0.176 \\
p=0.675\end{array}$ \\
\hline Length of Ventilation & $0.0[0.0-21.0]$ & $0.0[0.0-27.0]$ & $\begin{array}{l}Z=-0.117 \\
p=0.907\end{array}$ \\
\hline PRISM score & $11.0[0.0-33.0]$ & $11.0[0.0-33.0]$ & $\begin{array}{l}Z=-0.105 \\
p=0.916\end{array}$ \\
\hline $\begin{array}{l}\text { Malignancy } \\
\text { No } \\
\text { Yes }\end{array}$ & $\begin{array}{c}104(\% 88.9) \\
13(\% 11.1)\end{array}$ & $\begin{array}{l}90(\% 78.3) \\
25(\% 21.7)\end{array}$ & $\begin{array}{l}\chi^{2}=4.038 \\
p=0.044\end{array}$ \\
\hline
\end{tabular}

PICU: Pediatric intensive care unit; PRISM: Pediatric risk of mortality score

difference was detected in SHSR of children diagnosed as intoxication, trauma, burns and others. Mean \pm SD length of stay in MV and PRISM score were $5.8 \pm 6.3$ days and 11.6 \pm 8 respectively. The PRISM scores were significantly higher in SHS exposed children compared with non-exposed ones (score were 5.8 days \pm 6.3 and $11.6 \pm 8$ respectively, $p=0.007$ ). Length of stay in PICU and on mechanical ventilation was significantly longer in SHS exposed compared to non-exposed children $(p<0.05)$.

\section{DISCUSSION}

The aim of the present study was to investigate the various potential effects of SHS on children hospitalized in the pediatric intensive care unit. The current study revealed that the children exposed to SHS had higher Pediatric Risk of Mortality scores and needed long duration of MV than those who did not get exposed to SHS. To our knowledge, this was the first study from Turkey to investigate the impact of SHS exposure on hospitalization and MV need in pediatric intensive care unit. Before Hawamdeh et al. (6) reported the evidence for a relationship between passive smoking and the hazards of disorders such as respiratory illness, coronary heart disease and sudden infant death syndrome in children.

The home is the main source of exposure to SHS particularly for young children whose parents face increased restrictions for smoking outside the home. Lack of education can limit awareness of the hazards of SHS and can account for the higher prevalence of smoking among less educated people Vitoria et al. (9) found that parental smoking in Portugal significantly affect SHS at home. The smoking prevalence in Turkey was determined to be $30.5 \%$ for the whole population, $46.1 \%$ for males and $15.7 \%$ for females (11). In our study, we found that $76.9 \%$ of children hospitalized in our PICU were exposed to SHS reflecting an increased velocity of SHS exposure for pediatric intensive care unit (PICU) admissions. The smoking rates were $75.2 \%, 58.4 \%$ and $40.6 \%$ for father, guest and mother respectively. We also found that $9.6 \%$ of mothers and $5.6 \%$ of fathers were illiterate and not educated enough to recognize the hazards of SHS on their children. In consistent with our findings, Zhang et al. (13) reported that education was one of the main influencing factors for individual smoking.

Many studies in this field showed that SHS has been associated with respiratory symptoms, impaired lung functions and asthma, cardiovascular diseases, developmental disorders and increased the risk of young adolescents tobacco use $(5,6,11,14)$. In a study evaluating the effect of SHS exposure on length of stay and other exacerbation severity indicators in children hospitalized for asthma; length of stay was significantly higher in exposed patients compared to non-exposed patients $(15,16)$. In addition to that intravenous steroid use, which was one of the severity indicator of asthma attack was significantly higher in exposed patients compared with non-exposed ones (15). In the present study SHS was significantly associated with high PRISM scores reflecting severity of disease. In SHS group $34.3 \%$ of the hospitalized patients had pneumonia, $47.9 \%$ had respiratory symptoms and $63 \%$ had underlying pulmonary diseases. Consequently, SHS patients had longer duration of hospital stay and longer time of respiratory support and mechanical ventilation.

The current study was conducted in a single tertiary institution, it would be better to conduct the same study in different parts of country as multicenter study. This was one of the limitations of the study.

In conclusion, SHS is related with increased rate of PICU admissions, severity of disease, increased diagnosis of malignancies, prolonged duration of mechanical ventilation and PICU stay. Besides, secondhand exposed patients are more likely to have low parental education level. Further studies in this 
field are warranted to study the impact of SHS and its potential side effects on pediatric patients. Global and national policies against smoking are important not only for the individuals who smoke but also their children to be protected from the severity of diseases and to stay away from the PICUs.

\section{Compliance with Ethical Standards:}

Conflict of Interest: On behalf of all authors, the corresponding author states that there is no conflict of interest.

Ethical approval: All procedures performed in studies involving human participants were in accordance with the ethical standards of the institutional and/or national research committee and with the 1964 Helsinki declaration and its later amendments or comparable ethical standards.

Informed consent: Informed consent was obtained from all individual participants included in the study.

\section{REFERENCES}

1. Oberg M,Jaakkola MS,Woodward A,Peruga A,Prüss-Ustün A. Worldwide burden of disease from exposure to second-hand smoke: a retrospective analysis of data from 192 countries. Lancet 2011;377:139-46.

2. Vineis P, Hoek G, Krzyzanowski M, Vigna-Taglianti F, Veglia F, Airoldi $L$, , et al. Lung cancers attributable to environmental tobacco smoke and air pollution in non-smokers in different European countries: a prospective study. Environ Health 2007;6:7.

3. Lee W, Lee S, Kim J, Kim J, Kim YK, Kim K, et al. Relationship Between Exposure to Second-Hand Smoke in the Workplace and Occupational Injury in the Republic of Korea. Ann Work Expo Health 2017;62:41-52.

4. González Barcala FJ, Takkouche B, Valdés L, Temes E, Leis R, Cabanas R, et al. Parental smoking and lung function in healthy children and adolescents. Arch Bronconeumol 2007;43:81-5.

5. Soesanti F, Uiterwaal CSPM, Grobbee DE, Hendarto A, Dalmeijer GW, Idris NS. Antenatal exposure to second hand smoke of nonsmoking mothers and growth rate of their infants. PLoS One 2019;14:e0218577.
6. Hawamdeh A, Kasasbeh FA, Ahmad MA. Effects of passive smoking on children's health: a review. East Mediterr Health $\mathrm{J}$ 2003;9:441-7.

7. Shive I. Correlations of indoor second-hand smoking, household smoking rules, regional deprivation and children mental health: Scottish Health Survey, 2013. Environ Sci Pollut Res Int 2015;22:9858-63.

8. Northrup TF, Green C, Evans PW, Stotts AL. Characteristics associated with intervention and follow-up attendance in a secondhand smoke exposure study for families of NICU infants. J Matern Fetal Neonatal Med 2015;28:1208-13.

9. Vitória PD, Machado JC, Araújo AC, Ravara SB, Samorinha C, Antunes $\mathrm{H}$, et al. Children's exposure to second hand smoke at home: a cross-sectional study in Portugal. Rev Port Pneumol 2015;21:178-84.

10. Renwick C, Wu Q, Breton MO, Thorley R, Britton J, Lewis S,et al. Cost-effectiveness of a complex intervention to reduce children's exposure to second-handsmoke in the home. BMC Public Health 2018;18:1252.

11. Ozer N, Kilickap M, Tokgozoglu L, Goksuluk H, Karaaslan D, Kayıkcioglu M, et al. Data on smoking in Turkey: Systematic review, meta-analysis and meta-regression of epidemiological studies on cardiovascular risk factors. Turk Kardiyol Dern Ars. 2018; 46: 60212.

12. Pollack MM, Patel KM, Ruttimann UE. Prism III: an updated Pediatric Risk of Mortality Score. Crit Care Med 1996; 24:743-52.

13. Zhang R, Cao Q, Lu Y. The analysis of cigarette smoking behaviors and its influencing factors among chinese urban and rural residents. Acta Univ Med Nanjing (Nat Sci) 2014;34:84-9.

14. Xi B, Liang Y, Liu Y, Yan Y, Zhao M, Ma C, et al. Tobacco use and second-hand smoke exposure in young adolescents aged 12-15 years: data from 68 low-income and middle-income countries. Lancet Glob Health 2016;4:e795-e805.

15. Andrews AL, Shirley N,Ojukwu E, Robinson M, Torok M, Wilson $\mathrm{KM}$. Is secondhand smoke exposure associated with increased exacerbation severity among children hospitalized for asthma? Hosp Pediatr 2015; 5: 249-55.

16. Smair S, Colin Y, Thomas S. Impact of environmental tobacco smoke on children admitted with status asthmaticus in the pediatric intensive care unit. Pediatric Pulmonol 2011; 46:224-9. 